Jurnal Akuntansi dan Bisnis : Jurnal Program Studi Akuntansi 7 (2) November 2021 ISSN 2443-3071 (Print) ISSN 2503-0337 (Online)

DOI: $10.31289 / \mathrm{iab} . v 7 \mathrm{i} 2.5725$

JURNAL AKUNTANSI DAN BISNIS

Jurnal Program Studi Akuntansi

Available online http://ojs.uma.ac.id/index.php/jurnalakundanbisnis

\title{
Pengaruh Pendapatan dan Beban terhadap Beban Pajak dengan Earning Before Interest and Tax sebagai Variabel Intervening
}

\author{
The Effect Revenue and Expenses on Tax Expenses With \\ Earnings Before Interest and Tax as Intervening Variable
}

\author{
Suriani Ginting*, Sonya Enda Natasha S Pandia \& Evi Juita Wailan'An \\ Jurusan Akuntansi, Sekolah Tinggi Ilmu Ekonomi Mikroskil, Indonesia
}

Diterima: 26 Agustus 2021 Direview: 26 Agustus 2021 Disetujui: 20 November 2021

*Coresponding Email: suriani@mikrioskil.ac.id

\section{Abstrak}

Beban pajak adalah Jumlah agregat beban pajak kini dan beban pajak tangguhan yang diperhitungkan atas laba akuntansi yang diakui pada satu periode Penelitian ini bertujuan untuk mengetahui dan menganalisis pengaruh pendapatan dan beban terhadap beban pajak dengan Earnings Before Income and Tax (EBIT) sebagai intervening pada perusahaan consumer goods yang terdaftar di Bursa Efek Indonesia periode 2015-2019. Populasi Penelitian sebanyak 54 perusahaan consumer goods dengan metode purposive sampling diperoleh jumlah sampel sebanyak 24 perusahaan dan 120 jumlah pengamatan. Metode Analisis data menggunakan metode Analisis regresi linear berganda dan analisis jalur dengan melakukan pengujian asumsi klasik terlebih dahulu. Hasil Penelitian EBIT mampu mengintervening pengaruh Pendapatan terhadap Beban Pajak pada perusahaan Consumer Goods yang terdaftar di Bursa Efek Indonesia Periode 2015-2019 tetapi EBIT tidak mampu mengintervening Pengaruh Beban terhadap Beban Pajak pada perusahaan Consumer Goods yang Terdaftar di Bursa Efek Indoneia Periode 20152019.

Kata Kunci: Beban Pajak; Earnings Before Interest; Tax Pendapatan; Beban

\begin{abstract}
Tax expense is the aggregate amount of current tax expense and deferred tax expense which is calculated on accounting profit recognized in one period. This study aims to determine and analyze the effect of revenue and expenses on the tax expense with Earnings Before Income and Tax (EBIT) as an intervening in consumer goods companies listed on the Indonesia Stock Exchange for the 2015-2019 period. The population of the study was 54 consumer goods companies with purposive sampling method obtained a total sample of 24 companies and 120 observations. Methods Data analysis uses multiple linear regression analysis and path analysis by testing the classical assumptions first. The results of the study show that EBIT is able to mediate the effect of Rvenue on Tax Expense on Consumer Goods companies listed on the Indonesia Stock Exchange for the 2015-2019 Period but EBIT is not able to mediate the Effect of Expenses on Tax Expense on Consumer Goods Companies Listed on the Indonesia Stock Exchange for the 2015-2019 Period
\end{abstract}

Keyword: Tax Expense; Earnings Before Interest and Tax ; Revenue; Expense

How to Cite: Ginting, S., Pandia, S.E.S.N.S., \& Wailan'An, E.J., (2021), Pengaruh Pendapatan dan beban Terhadap beban Pajak dengan Earnings Before Interest and Tax sebagai Variabel Intervening Jurnal Akuntansi dan Bisnis : Jurnal Program Studi Akuntansi, 7(2) : 207-216 
Suriani Ginting, Sonya Enda Natasha S Pandia \& Evi Juita Wailan'An, Pengaruh Pendapatan dan beban Terhadap beban Pajak dengan Earnings Before Interest and Tax sebagai Variabel Intervening

\section{PENDAHULUAN}

Pajak adalah iuran rakyat kepada Kas Negara berdasarkan Undang-Undang (yang dapat dipaksakan) dengan tidak mendapatkan jasa timbal (kontra prestasi) yang langsung dapat dtunjukkan dan yang digunakan untuk membayar pengeluaran umum (Waluyo, 2017). Beban pajak ditentukan berdasarkan besarnya jumlah pendapatan atau penghasilan yang diterima wajib pajak (WP). Beban pajak adalah Jumlah agregat beban pajak kini dan beban pajak tangguhan yang diperhitungkan atas laba akuntansi yang diakui pada satu periode (Martani, 2012). Beban pajak akan dipadankan dengan laba akuntansi yang diakui pada periode tersebut. Beban pajak kini adalah Jumlah pajak yang harus dibayar oleh wajib pajak yang dihitung dari penghasilan kena pajak hasil rekonsiliasi fiskal yang dikalikan tarif pajak koreksi fiskal harus dilakukan karena adanya perbedaan perlakuan atas pendapatan maupun beban yang berbeda antara standar akuntansi dengan peraturan perpajakan yang berlaku Beban pajak atau Pajak Penghasilan dapat di artikan sebagai jumlah total pajak kini dan pajak tangguhan yang diperhitungkan dalam menentukan laba atau rugi pada suatu periode.Setiap rentang penghasilan memiliki tarif pajak yang masing-masing sesuai dengan peraturan pemerintah yang memberlakukan demi keadilan kewajiban wajib pajak, yaitu jika penghasilan wajib pajak semakin tinggi maka beban pajak yang akan ditanggung juga semakin tinggi. Namun, harapan pemerintah untuk realisasi penerimaan negara dari pajak penghasilan masih belum tercapai maksimal. Dalam beberapa tahun belakangan penerimaan pajak tercatat melambat dan realisasi penerimaan juga tidak sesuai dengan apa yang menjadi standar yang telah ditetapkan. Hal ini dapat di lihat di gambar 1 (Gianto, 2019).

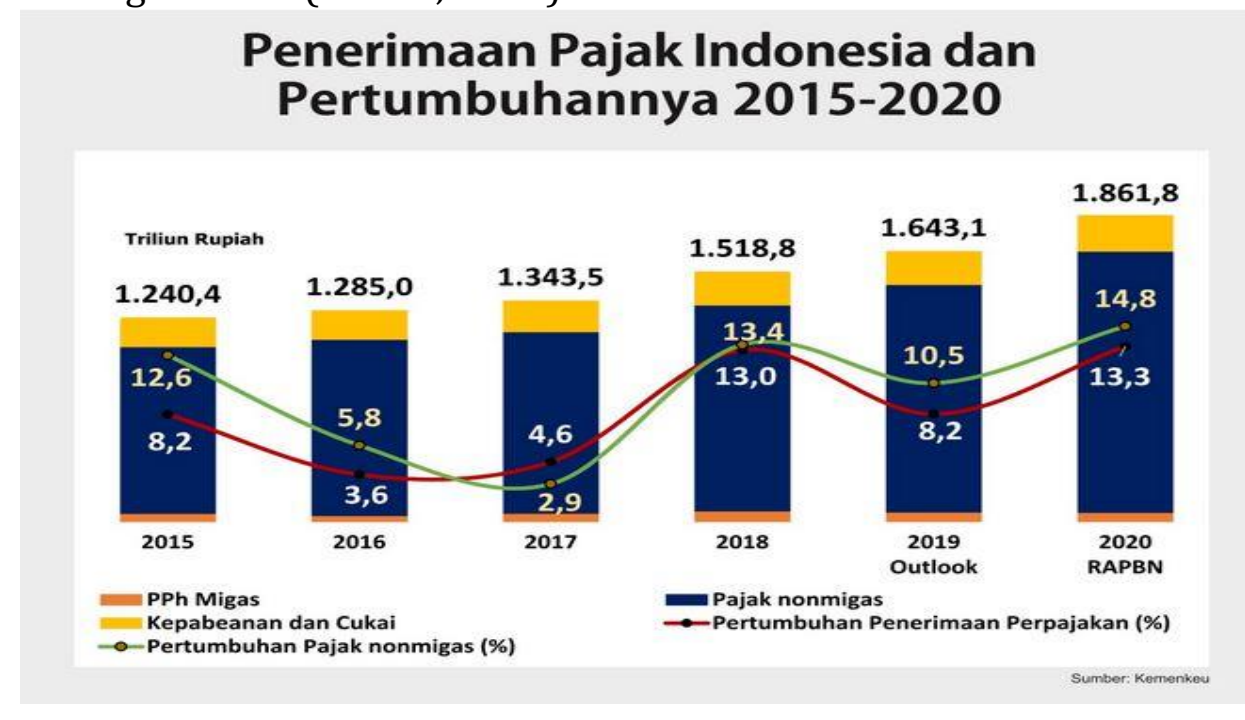

\section{Gambar 1 Grafik Penerimaan Pajak di Indonesia dan Pertumbuhannya}

Komponen realisasi pendapatan negara masih mengalami kontraksi, penerimaan perpajakan tumbuh negatif dibandingkan tahun sebelumnya disebabkan perlambatan kegiatan ekonomi dan pemanfaatan insentif fiscal. "Penerimaan pajak (hingga Agustus 2020) Rp676, 9 triliun atau 56,5\% dari target penerimaan pajak tahun ini berdasarkan Perpres 72 tahun 2020, maka penerimaan pajak sampai akhir Agustus adalah kontraksi 15,6\%," jelas Menkeu. Menkeu melanjutkan bahwa, penurunan sangat tajam terjadi pada penerimaan Pajak Penghasilan Minyak dan Gas (PPh Migas) yang realisasinya sampai Agustus 2020 ini adalah sebesar Rp21,6 triliun. Penerimaan PPH Migas mengalami kontraksi yang cukup dalam yaitu 45,2\%, apabila dibandingkan Agustus tahun lalu yang sebesar Rp39,5 triliun (Kemenkeu, 2020). 
Teori Agensi (agency theory), atau yang biasa juga disebut contracting theory, merupakan salah satu aliran riset akuntansi terpenting. Oleh karena itu, teori agensi berfokus pada biaya-biaya pemantauan dan penyelenggaraan hubungan antara berbagai pihak. Hubungan keagenan antar berbagai pihak tersebut banyak ditentukan/diatur berdasarkna angka-angka akuntansi. Hubungan keagenan tersebut mencakup perjanjian pinjaman, kompensasi manajemen, kontrak-kontrak, ukuran perusahaan. Pernajanjian pinjaman sering sekali menentukan tingkat rasio, seperti rasio utang terhadap ekuitas, dan peanggaran terhadap tingkat maksimum tersebut akan menyebabkan perusahaan mengalami kesulitan teknis. Semakin dekat batasan utang terhadap ekuitas, semakin mungkin manajemen akan memilih alternative-alternatif akuntansi yang akan meningkatkan income (Bastian, 2006).

Penelitian ini menggunakan Earnings Before Interest and Tax (EBIT) sebagai variabel intervening EBIT disebut juga dengan laba operasional sebelum bunga dan pajak. Keberhasilan kegiatan suatu perusahaan dapat diukur berdasarkan nilai EBIT. EBIT dapat menjadi pedoman bagi investor untuk menilai perusahaan. EBIT juga dapat menjadi acuan untuk mengukur konsep dan kegiatan sebuah bisnis berjalan secara efektif serta menentukan kemampuan perusahaan dalam melunasi kewajibannya. EBIT menjadi dasar perhitungan dan penentuan tarif pajak yang dikenakan terhadap perusahaan. Jika Nilai EBIT semakin tinggi maka besarnya beban pajak akan meningkatJumlah EBIT diperoleh dari pendapatan dikurangi beban.

Pendapatan merupakan penghasilan yang timbul dari aktivitas perusahaan, yang sangat penting di dalam kegiatan perusahaan. Pendapatan merupakan kenaikan manfaat ekonomi selama suatu periode akuntansi dalam bentuk arus masuk atau penambahan aset atau penurunan liabilitas yang mengakibatkan nkenaikan ekuitas yang tidak berasal dari kontribusi pemegang saham. (Kieso, 2017) Pendapatan sangat besar pengaruhnya terhadap keberlangsungan suatu usaha, semakin besar pendapatan yang diperoleh maka semakin besar kemampuan perusahaan untuk membiayai seluruh pengeluaran atau biaya operasional. Pendapatan berdampak terhadap laba perusahaan, sebab pendapatan dikurangi beban akan menjadi dasar dalam penentuan laba. Hasil penelitian sebelumnya menyatakan bahwa secara signifikan terdapat pengaruh pendapatan terhadap laba (Gunawan, 2019). Namun berbeda dengan penelitian lain yang menyatakan bahwa tidak ada pengaruh pendapatan terhadap laba (Zulkarnain, 2020). Pendapatan menjadi dasar perhitungan dan penentuan besarnya laba yang diperoleh perusahaan disetiap periode. Pendapatan perusahaan besar dan beban yang dikeluarkan dapat diminimalkan maka semakin besar pula beban pajak yang akan ditanggung perusahaan. Sejalan dengan hasil penelitian terdahulu yang menyatakan bahwa Pendapatan berpengaruh terhadap beban pajak (Remofa, 2019). Namun, berbeda dengan penelitian yang menyatakan beban tidak berpengaruh terhadap beban pajak (Filsi, 2012).

Beban bagi perusahaan mencerminkan arus keluar, pengurangan asset dan timbulnya kewajiban dalam kegiatan operasional perusahaan untuk menghasilkan pendapatan. Beban merupakan penurunan manfaat ekonomi selama suatu periode akuntansidalam bentuk arus kas keluar atau berkurangnya aset atau terjadinya liabilitas yang mengakibatkan penurunan ekuitas yang tidak terkait dengan distribusi kepada pemegang saham (Kieso, 2017) Setiap perusahaan harusnya dapat memanajemen beban seefisien mungkin karena akan berdampak pada besaran laba yang akan diperoleh setiap periode. Hasil penelitian terdahulu menyatakan bahwa beban berpengaruh terhadap laba (Sukmawati, 2020). Namun, tidak sejalan dengan hasil penelitian yang menyatakan bahwa beban tidak berpengaruh terhadap laba (Pasaribu, 2017). Besarnya beban juga akan menjadi penentu kewajiban pajak yang akan ditanggung perusahaan, karena pendapatan besar beban dapat 
diminimalkan maka laba tinggi dan beban pajak juga akan semakin besar, sesuai dengan arah laba yang diperoleh. Sesuai dengan hasil penelitian terdahulu menyatakan bahwa beban berpengaruh terhadap beban pajak (Remofa, 2019). Namun, bertolak belakang dengan penelitian yang menyatakan bahwa beban tidak berpengaruh terhadap beban pajak (Filsi, 2012).

Rumusan masalah penelitian ini adalah (1) Apakah Pendapatan dan Beban berpengaruh secara simultan maupun parsial terhadap EBIT pada perusahaan Consumer Goods Industry yang Terdaftar di Bursa Efek Indonesia Periode 2015-2019? (2) Apakah Pendapatan, beban dan EBIT berpengaruh secara simultan maupun parsial terhadap beban pajak Pada perusahaan Consumer Goods Industry yang Terdaftar di BEI Periode 2015-2019? (3) Apakah Pendapatan dan Beban berpengaruh terhadap beban pajak melalui EBIT Pada perusahaan Consumer Goods Industry yang Terdaftar di BEI Periode 2015-2019?

Pendapatan sangat besar pengaruhnya terhadap keberlangsungan suatu usaha, semakin besar pendapatan yang diperoleh maka semakin besar kemampuan perusahaan untuk membiayai seluruh pengeluaran atau biaya operasional. Pendapatan juga memiliki dampak besar terhadap penentuan laba perusahaan, karena pendapatan menjadi dasar dalam penentuan laba dalam suatu perusahaan. Hal ini sejalan dengan penelitian yang menyatakan bahwa Pendapatan berpengaruh terhadap EBIT. Pendapatan perusahaan tinggi maka hal tersebut akan menjadi dasar perhitungan dan penentuan besarnya laba yang akan diperoleh perusahaan disetiap periode. Semakin tinggi Pendapatan perusahaan otomatis semakin besar pula beban pajak yang akan dibayarkan oleh perusahaan. Hal ini sejalan dengan penelitian yang menyatakan bahwa Pendapatan berpengaruh terhadap Beban Pajak (Wagini, Andalas, \& Susena, 2019).

Semakin tinggi pendapatan suatu perusahaan maka semakin besar pula laba yang akan diperoleh dan hal tersebut akan berdampak pada jumlah beban pajak yang akan dibayarkan oleh perusahaan akan semakin tinggi

$\mathrm{H}_{1 \mathrm{a}}$ : Pendapatan berpengaruh terhadap EBIT

$\mathrm{H}_{1 \mathrm{~b}}$ : Pendapatan berpengaruh terhadap Beban Pajak

$\mathrm{H}_{1}$ : Pendapatan berpengaruh terhadap Beban Pajak melalui EBIT

Beban bagi perusahaan yaitu menggambarkan arus keluar, pengurangan asset dan timbulnya kewajiban dalam kegiatan operasional perusahaan untuk menghasilkan pendapatan. Setiap perusahaan harusnya dapat memanajemen beban seefektif dan seefisien mungkin karena akan berpengaruh pada besaran laba yang akan diperoleh setiap periode. Besarnya total beban juga akan menjadi penentu kewajiban pajak yang akan ditanggung perusahaan, karena pendapatan besar dan beban dapat diminimalkan maka laba tinggi dan otomatis beban pajak juga akan semakin besar, sesuai dengan arah laba yang diperoleh (Wagini, Andalas, \& Susena, 2019). Ketika beban perusahaan mengalami peningkatan maka EBIT akan mengalami penurunan dengan EBIT Mengalami penurunan otomatis beban pajak akan semakin menurun

$\mathrm{H}_{2 \mathrm{a}}$ : Beban berpengaruh terhadap EBIT

$\mathrm{H}_{2 \mathrm{~b}}$ : Beban berpengaruh terhadap Beban Pajak

$\mathrm{H}_{2 c}$ : Beban berpengaruh terhadap Beban Pajak melalui EBIT

\section{METODE PENELITIAN}

Populasi yang digunakan dalam penelitian ini adalah perusahaan manufaktur yang terdaftar di Bursa Efek Indonesia (BEI) pada periode 2015-2019. Teknik pengambilan sampel dalam penelitian ini adalah menggunakan metode Purposive Sampling yaitu tipe pemilihan sampel tidak secara acak tetapi yang informasinya diperoleh dengan 
menggunakan pertimbangan tertentu dan umumnya disesuaikan dengan masalah penelitian dan tujuan penelitian.

\section{Variabel penelitian dan Pengukuran Variabel Variabel Dependen: Beban Pajak}

Definisi pajak menurut Undang-Undang Nomor 16 Tahun 2009 tentang perubahan keempat atas Undnag-Undang Nomor 6 Tahun 1983 tentang Ketentuan Umum dan Tata Cara Perpajakan pada Pasal 1 Ayat 1 berbunyi pajak adalah kontribusi wajib kepada negara yang terutang oleh orang pribadi atau badan yang bersifat memaksa berdasarkan undnagundang, dengan tidak mendapatkan imbalan secara langsung dan digunakan untuk keperluan negara bagi sebesar-besarnya kemakmuran rakyat (Mardiasmo, 2018).

Pada prinsipnya, total beban pajak pengahasilan adalah jumlah pajak yang dikenakan atas seluruh transaksi yang dilakukan perusahaan sepanjang satu tahun. Total beban pajak penghasilan yang dilaporkan dalam laporan laba rugi periode berjalan ini pada umumnya timbul dari dua kewajiban, yaitu; (1) kewajiban pajak saat ini, yang terhutang sebagai konsekuensi dari besarnya laba kena pajak untuk periode berjalan, dan (2) kewajiban pajak yang ditangguhkan, sebagai konsekuensi dari besarnya jumlah kena pajak di masa yang akan datang. Sedangkan aset pajak yang ditangguhkan justru akan mengurangi total beban pajak penghasilan karena menimbulkan manfaat pajak tangguhan. Kewajiban pajak saat ini adalah kewajiban pajak yang secara hukum atau legal sudah ada atau terhutang (berdasarkan ketentuan perpajakan) atas besarnya laba kena pajak periode berjalan. Sedangkan kewajiban pajak yang ditangguhkan adalah perkiraan pajak penghasilan atas pendapatan yang sudah terjadi (menurut akuntansi), tetapi berdasarkan ketentuan perpajakan belum terhutang pajak (karena belum ada penerimaan kas); atau dengan kata lain bahwa kewajiban pajak ini secara legal belum ada, dan baru akan resmi kena pajak atau memerlukan pembayaran pajak di periode mendatang (oleh sebab itu dikatakan sebagai kewajiban pajak yang ditangguhkan) (Hery, 2015). Kewajiban pajak yang ditangguhkan ini timbul karena adanya perbedaan sementara dalam hal pengakuan pendapatan dan beban antara menurut akuntansi dengan menurut pajak. Laba menurut akuntansi (laba komersil) diukur berdasarkan akrual (accrual basis), sedangkan laba menurut pajak (laba kena pajak atau laba fiskal) berpatokan pada dasar kas (cash basis). Dinamakan perbedaan sementara karena secara keseluruhan (setelah melalui beberapa periode), dampak dari perbedaan tersebut terhadap laba akuntansi maupun laba menurut pajak akan sama. Pengakuan atas kewajiban pajak yang ditangguhkan sebagai beban pajak penghasilan dalam periode berjalan adalah untuk menjamin bahwa seluruh beban yang terkait dengan pendapatan yang sudah terjadi selama periode berjalan dilaporkan dalam laporan laba rugi periode berjalan. Dalam akuntansi, hal ini juga sejalan dengan konsep penandingan (Hery, 2015).

\section{Variabel Intervening: EBIT}

Konsep laba perusahaan ada beberapa, antara lain konsep laba bedasarkan teori laba menanggung resiko, teori laba friksional, teori laba monopoli, teori laba inovasi, dan teori laba efisiensi managerial. Walaupun demikian, baik bagi para praktisi maupun para akademisi, perlu diketahui bahwa laba bukanlah suatu sistem yang sempurna.Oleh sebab itu, konsep laba maksimum hanya mungkin terbentuk jika total revenue (TR) kurang total cost (TC) nilainya adalah positif terbesar, dimana marginal revenue (MR) cenderung turun dan marginal cost (MC) bertendensi meningkat. Agar laba sebelum pajak tidak keserap terlalu besar oleh biaya bunga pinjaman (interest expanses of loans) maka perlu memahami struktur modal yang optimal (Bararuallo, 2019) 
Laba operasional ditambah dengan pendapatan dan keuntungan lain-lain dan dikurangkan dengan beban dan kerugian lain-lain akan menghasilkan laba sebelum pajak penghasilan. Ukuran laba ini mencerminkan kinerja perusahaan selama periode berjalan (yang meliputi aktivitas utama maupun aktivitas sekunder), namun sebelum memperhitungkan besarnya pajak penghasilan (Hery, 2015)

\section{Variabel Independen: \\ Pendapatan}

Kenaikan manfaat ekonomi selama suatu periode akuntansi dalam bentuk arus masuk atau penambahan aset atau penurunan liabilitas yang mengakibatkan kenaikan ekuitas yang tidak berasal dari kontribusi pemegang saham. Pendapatan dapat diartikan sebagai pemasukan manfaat ekonomi selama suatu periode yang timbul dalam pelaksanaan aktivitas normal perusahaan (Kieso, Weygandt, \& Warfield, 2017)

\section{Beban}

Beban (expenses) adalah penurunan manfaat ekonomi selama suatu periode akuntansi dalam bentuk arus keluar atau berkurangnya aset atau terjadinya liabilitas yang mengakibatkan penurunan ekuitas yang tidak terkait dengan distribusi kepada pemegang saham (Kieso, Weygandt, \& Warfield, 2017).

\section{Metode Analisis Data}

Dalam menganalisis data yang ada, peneliti menggunakan metode analisis statistik dengan bantuan program SPSS 25. Dalam penelitian ini menggunakan model regresi linear berganda dan analisis jalur dengan terlebih dahulu dilakukan pengujian asumsi klasik. Analisis regresi linear berganda dilakukan untuk mengetahui seberapa besar hubungan antara variable dependen dengan variable independen. Persamaan regresi linear berganda yang digunakan dalam penelitian ini adalah sebagai berikut (Ghozali, 2018).

$$
\begin{aligned}
& Y_{1}=a+b_{1} X_{1}+b_{2} X_{2}+e \\
& Y_{2}=a+b_{1} X_{1}+b_{2} X_{2}+b_{3} Y_{1}+e
\end{aligned}
$$

\section{HASIL DAN PEMBAHASAN \\ Pengujian Hipotesis Pertama Setelah Transformasi Data Uji Signifikansi Simultan (Uji Statistik - F)}

Tabel 1 Hasil Pengujian Hipotesis Pertama Uji Simultan (Uji Statistik - F)

\begin{tabular}{ccccccc}
\hline & Model & Sum of Squares & df & Mean Square & F & Sig. \\
\hline \multirow{2}{*}{1} & Regression & 52,270 & 2 & 26,135 & 86,379 &, $000^{\mathrm{b}}$ \\
& Residual & 33,282 & 110 &, 303 & & \\
& Total & 85,551 & 112 & & & \\
\hline
\end{tabular}

a. Dependent Variable: Lg10_Ebit

b. Predictors: (Constant), BEBAN, PENDAPATAN

Berdasarkan Tabel 1 dapat dilihat bahwa nilai $\mathrm{F}_{\text {hitung }}$ menunjukkan nilai sebesar 86,379 dengan nilai $F_{\text {tabel }}$ sebesar 3,08 dengan $\mathrm{df}$ pembilang $=2$, df penyebut $=110$ dan tarif signifikan $\alpha=0,05$ sehingga diperoleh hasil $F_{\text {hitung }}>F_{\text {tabel }}(86,379>3,08)$ diketahui bahwa nilai signifikan 0,00 lebih kecil dari 0,05 sehingga dapat dikatakan bahwa secara simultan variabel Beban dan Pendapatan berpengaruh signifikan terhadap variable Lg10Ebit 


\section{Uji Signifikansi Parsial (Uji Statistik t)}

Tabel 2 Hasil Pengujian Hipotesis Pertama Uji Parsial (Uji Statistik - t)

\begin{tabular}{|c|c|c|c|c|c|c|}
\hline \multirow{2}{*}{\multicolumn{2}{|c|}{ Model }} & \multicolumn{2}{|c|}{ Unstandardized Coefficients } & \multirow{2}{*}{$\begin{array}{c}\text { Standardized Coefficients } \\
\text { Beta }\end{array}$} & \multirow[b]{2}{*}{$\mathrm{l}$} & \multirow[b]{2}{*}{ Sig. } \\
\hline & & $\mathrm{B}$ & Std. Error & & & \\
\hline \multirow[t]{3}{*}{1} & (Constant) & 11,335 & ,061 & & 184,306 & 000 \\
\hline & PENDAPATAN & $1,090 \mathrm{E}-13$ & 000 & 3,669 & 3,074 & 003 \\
\hline & BEBAN & $-1,009 \mathrm{E}-13$ & 000 & $-2,905$ & $-2,433$ & 017 \\
\hline
\end{tabular}

a. Dependent Variable: Lg10_Ebit

Berdasarkan Tabel 2 dapat dilihat bahwa Pendapatan dan Beban berpengaruh signifikan terhadap EBIT

\section{Uji Koefisien Determinasi}

Tabel 3 Hasil Pengujian Hipotesis Pertama Koefisien Determinasi $\left(R^{2}\right)$

\begin{tabular}{ccccc}
\hline Model & $\mathrm{R}$ & $\mathrm{R}$ Square & Adjusted R Square & Std. Error of the Estimate \\
\hline 1 &, $782^{\mathrm{a}}$ &, 611 &, 604 &, 55005 \\
\hline
\end{tabular}

a. Predictors: (Constant), BEBAN, PENDAPATAN

b. Dependent Variable: Lg10_Ebit

Berdasarkan Tabel 5.20 nilai Koefisien (R) sebesar 0,611 dan Nilai Adjusted R Square sebesar 0,604 atau 60,4\%. Hal ini berarti variabel Pendapatan dan Beban dapat menjelaskan variabel Lg10_Ebit sebesar 60,4 \% sedangkan sisanya $39,6 \%$ dijelaskan oleh variabel lain diluar model estimasi ini.

\section{Pengujian Hipotesis Kedua Setelah Transformasi Data Uji Signifikansi Simultan (Uji Statistik - F)}

Tabel 4 Hasil Pengujian Hipotesis Kedua Uji Simultan (Uji Statistik - F)

\begin{tabular}{ccccccc}
\hline & Model & Sum of Squares & df & Mean Square & F & Sig. \\
\hline \multirow{2}{*}{1} & Regression & 87,188 & 3 & 29,063 & 10706,629 &, $000^{\mathrm{b}}$ \\
& Residual &, 296 & 109 &, 003 & & \\
& Total & 87,484 & 112 & & & \\
\hline
\end{tabular}

a. Dependent Variable: Lg10_Beban_Pajak

b. Predictors: (Constant), Lg10_Ebit, BEBAN, PENDAPATAN

Berdasarkan Tabel 5.21 dapat dilihat bahwa nilai $F_{\text {hitung menunjukkan nilai }}$ sebesar 10706,629 dengan nilai $F_{\text {tabel }}$ sebesar 2,69 dengan df pembilang $=3$, df penyebut $=109$ dan tarif signifikan $\alpha=0,05$ sehingga diperoleh hasil $F_{\text {hitung }}>F_{\text {tabel }}(10706,629>$ 2,69) diketahui bahwa nilai signifikan $0,00<0,05$ sehingga dapat dikatakan bahwa secara simultan variabel Beban, Pendapatan dan Lg10Ebit berpengaruh signifikan terhadap variable Lg10_Beban Pajak

\section{Uji Signifikansi Parsial (Uji Statistik t)}

Tabel 5 Hasil Pengujian Hipotesis Kedua Uji Parsial (Uji Statistik - t)

\begin{tabular}{|c|c|c|c|c|c|c|}
\hline & & \multicolumn{2}{|c|}{ Unstandardized Coefficients } & \multicolumn{2}{|c|}{ Standardized Coefficients } & \multirow[b]{2}{*}{ Sig. } \\
\hline & Model & B & Std. Error & Beta & $\mathrm{t}$ & \\
\hline \multirow[t]{4}{*}{1} & (Constant) &,- 678 & ,103 & & $-6,611$ & 000 \\
\hline & PENDAPATAN & $-8,793 \mathrm{E}-15$ & 000 &,- 293 & $-2,511$ & 014 \\
\hline & BEBAN & $1,050 \mathrm{E}-14$ & 000 & 299 & 2,603 & 011 \\
\hline & Lg10_Ebit & 1,007 & ,009 & ,996 & 111,507 & 000 \\
\hline
\end{tabular}

a. Dependent Variable: Lg10_Beban_Pajak 
Suriani Ginting, Sonya Enda Natasha S Pandia \& Evi Juita Wailan'An, Pengaruh Pendapatan dan beban

Terhadap beban Pajak dengan Earnings Before Interest and Tax sebagai Variabel Intervening

Berdasarkan Tabel 5 dapat dilihat bahwa Pendapatan dan Beban berpengaruh signifikan terhadap Beban Pajak

\section{Uji Koefisien Determinasi}

Tabel 6 Hasil Pengujian Hipotesis Kedua Koefisien Determinasi $\left(\mathbf{R}^{2}\right)$

\begin{tabular}{ccccc}
\hline Model & R & R Square & Adjusted R Square & Std. Error of the Estimate \\
\hline 1 &, $998^{\mathrm{a}}$ &, 997 &, 997 &, 05210 \\
\hline \multicolumn{5}{c}{ a. Predictors: (Constant), Lg10_Ebit, BEBAN, PENDAPATAN } \\
b. Dependent Variable: Lg10_Beban_Pajak
\end{tabular}

Berdasarkan Tabel 6 nilai Koefisien R Square sebesar 0,997 sama dengan Nilai Adjusted R Square sebesar 0,997 atau 99,7 \%. Hal ini berarti variabel Pendapatan, Beban dan Lq10_Ebit dapat menjelaskan variabel Lg10_Beban Pajak sebesar 99,7 \% sedangkan sisanya $3 \%$ dijelaskan oleh variabel lain diluar model estimasi ini.

\section{Pengujian Hipotesis Ketiga (Analisis Jalur)}

Tabel 7 Pengujian Path Analysis

\begin{tabular}{ccccc}
\hline Independen & $\begin{array}{c}\text { Pengaruh } \\
\text { Langsung (P1) }\end{array}$ & $\begin{array}{c}\text { Pengaruh Tidak Langsung } \\
\text { (P2 x P3) }\end{array}$ & $\begin{array}{c}\text { Pengaruh } \\
\text { Total }\end{array}$ & Kesimpulan \\
\hline Pendapatan & $-0,293$ & $3,669 \times 0,996=3,6543$ & 3,3613 & Intervening \\
\hline Beban & 0,299 & $-2,433 \times 0,996=-2,4232$ & $-2,1242$ & $\begin{array}{c}\text { Tidak berperan sebagai } \\
\text { Intervening }\end{array}$ \\
\hline
\end{tabular}

Berdasarkan tabel 7, dapat diketahui bahwa hasil analisis jalur menunjukkan EBIT mampu berperan dalam mengintervening pada Pendapatan, sedangkan untuk Beban tidak mampu sehingga terbentuklah kerangka konseptual analisis jalur sebagai berikut:

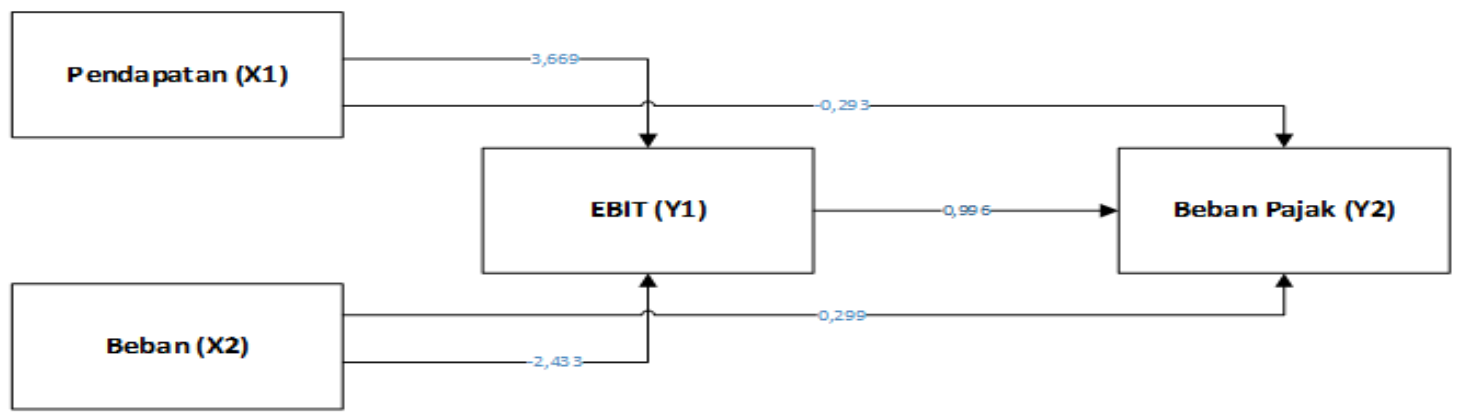

Gambar 2 Kerangka Konseptual Analisis Jalur

\section{Pengaruh Pendapatan terhadap Beban Pajak melalui EBIT}

Hasil penelitian pada pengujian hipotesis pertama menunjukkan bahwa Pendapatan berpengaruh positif terhadap EBIT. Penelitian ini sejalan dengan hasil penelitian yang menyatakan bahwa Pendapatan berpengaruh signifikan terhadap Laba (Pasaribu, 2017), tetapi bertentangan dengan hasil penelitian lainnya yang menyatakan Pendapatan tidak berpengaruh terhadap Laba (Zulkarnain, 2020). Pendapatan merupakan hal yang sangat penting bagi suatu perusahaan, karena pendapatan tersebut akan menjadi obyek atas kegiatan perusahaan. Pendapatan sangat berpengaruh pada kelangsungan suatu usaha, semakin besar pendapatan yang diperoleh, maka akan sejalan dengan meningkatnya Laba yang diperoleh perusahaan jika pengeluaran atau bebab- beban perusahaan dapat dikelola dengan efisien.

Hasil penelitian pada pengujian hipotesis kedua menyatakan bahwa Pendapatan berpengaruh positif terhadap Beban Pajak. Penelitian ini sejalan dengan hasil penelitian 
yang menyatakan bahwa Pendapatan berpengaruh signifikan terhadap Beban Pajak (Remofa, 2019), tetapi bertentangan dengan hasil penelitian lainnya yang menyatakan Pendapatan tidak berpengaruh terhadap Beban Pajak (Filsi, 2012). Jika pendapat perusahaan mengalami peningkatan maka beban pajak juga akan ikut meningkat, untuk itu diharapkan pihak manajemen tetap memperhatikan kinerjanya dengan baik. Pendapatan menjadi unsur yang harus diperhatikan dalam melakukan suatu usaha karena pendapatan merupakan salah satu tolak ukur keberhasilan dari suatu perusahaan. Semakin pendapatan yang diperoleh, maka semakin besar kemampuan usaha untuk membiayai segala pengeluaran dan beban-beban, termasuk beban pajak penghasilan perusahaan.

Hasil pengujian pada Hipotesis ketiga pada Analisis Jalur menunjukkan bahwa EBIT mampu mengintervening Pendapatan dengan Beban Pajak. Dalam perhitungan beban pajak sesuai dengan tarif yang ditetapkan pemerintah yaitu, EBIT atau laba sebelum bunga dan pajak merupakan dasar dalam menghitung besaran beban pajak penghasilan setiap periodenya.

\section{Pengaruh Beban terhadap Beban Pajak melalui EBIT}

Hasil penelitian pada pengujian hipotesis pertama menunjukkan Beban berpengaruh negatif terhadap EBIT. Hasil Penelitian ini sejalan dengan hasil Penelitian sebelumnya yang menyatakan Beban berpengaruh signifikan terhadap Laba (Sukmawati, 2020), tetapi hasil penelitian ini tidak sejalan dengan penelitian terdahulu yang menyatakan Beban tidak berpengaruh signifikan terhadap Laba (Pasaribu, 2017). Beban di dalam laporan keuangan yaitu menjadi pengurang pendapatan perusahaan. Semakin besar jumlah pengeluaran atau beban perusahaan maka EBIT akan berkurang.

Hasil Penelitian pada pengujian hipotesis kedua menyatakan bahwa Beban berpengaruh positif terhadap beban pajak, Hasil Penelitian ini sejalan dengan hasil Penelitian sebelumnya yang menyatakan Beban berpengaruh signifikan terhadap Beban Pajak (Remofa, 2019), tetapi hasil penelitian ini tidak sejalan dengan penelitian terdahulu yang menyatakan Beban tidak berpengaruh signifikan terhadap Beban pajak (Filsi, 2012). Jika Jumlah beban perusahaan mengalami peningkatan tetapi beban dalam hal ini bukan merupakan beban yang kena pajak maka perusahaan perlu memperhatikan perencanaan beban perusahaan agar mampu mengurangi beban pajak perusahaan. Ketika beban perusahaan mengalami peningkatan maka beban pajak juga mengalami peningkatan, hal ini karena ketika perusahaan membayar beban tetapi jumlah pendapatan perusahaan tidak mengalami peningkatan hal ini mengakibatkan beban pajak mengalami peningkatan. Maka dengan terjadinya peningkatan beban pada perusahaan tentu beban pajak juga akan ikut meningkat sesuai dengan tingkat pendapatan yang diperoleh perusahaan.

Hasil pengujian pada Hipotesis ketiga pada Analisis Jalur menunjukkan bahwa EBIT tidak mampu mengintervening Beban dengan Beban Pajak, ketika perusahaan melakukan perencanaan pajak melalui jumlah beban yang terkendali maka beban pajak perusahaan akan dapat di efektifkan. Hal ini menunjukkan bahwa EBIT tidak diperlukan sebagai variable intervening karena perusahaan telah melakukan perencanaan pajak secara efektif.

\section{SIMPULAN}

Penelitian ini menunjukkan bahwa secara langsung Pendapatan dan Beban berpengaruh terhadap Beban Pajak pada perusahaan Consumer Goods Industry yang Terdaftar di BEI Periode 2015-2019 dan sejalan dengan Penelitian terdahulu. (Wagini 2019) Berdasarkan hasil uji Path menunjukkan EBIT mampu mengintervening pengaruh 
Pendapatan terhadap Beban Pajak pada perusahaan Consumer Goods Industry yang Terdaftar di BEI Periode 2015-2019. Hal ini menunjukkan EBIT memberikan kontribusi dalam mempengaruhi Pendapatan terhadap Beban Pajak (Wagini, 2019) Hasil Uji Path pada variabel Beban menunjukkan EBIT tidak mampu mengintervening Pengaruh Beban terhadap Beban Pajak pada perusahaan Consumer Goods Industry yang Terdaftar di BEI Periode 2015-2019. Beban Pajak ditentukan dari besarnya jumlah laba yang diperoleh perusahaan. (Waluyo, 2017) Laba diperoleh dari selisih antara pendapatan dengan beban melalui perhitungan Laba-rugi sehingga secara langsung Beban berpengaruh terhadap beban pajak. Melalui Penelitian ini diharapkan pihak Manajemen dapat meningkatkan pendapatan dan mengurangi beban karena secara langsung Pendapatan dan Beban berpengaruh terhadap Beban Pajak.. Disamping itu Pihak Manjemen perlu mengoptimalkan pembayaran pajak dengan tetap mematuhi undang undang perpajakan yang berlaku. Keterbatasan dalam Penelitian ini hanya terdapat dua variabel independen yaitu Pendapatan dan Beban sehingga disarankan kepada peneliti selanjutnya agar dapat memperluas penelitian dengan menambah variabel Perencanaan Pajak sebagai variabel Independen. Perencanaan pajak akan mempengaruhi jumlah beban pajak yang akan dibayar perusahaan. Perencanaan pajak yang efektif akan membantu Manajemen dalam mengefisiensikan beban pajak perusahaan.

\section{DAFTAR PUSTAKA}

Bararuallo, F., (2019). Pengantar Bisnis: Prinsip, Konsep, Teori, dan Strategi.

Bastian, I., (2006). Akuntansi Pendidikan. Yogyakarta: Erlangga.

Filsi, C. J., (2012). Pengaruh Pendapatan dan Beban Terhadap Pajak.

Ghozali, I., (2018). Aplikasi Analisis Multivariate Dengan Program IBM SPSS 25. Semarang: Badan Penerbit Universitas Diponegoro.

Gianto., (2019, Agustus Kamis). Retrieved from Berita Satu: https://www.beritasatu.com/beritagrafik/571033/penerimaan-pajak-20152020

Gunawan, E., (2019). Pengaruh Laba Komersial, Pendapatan Pajak Tangguhan Terhadap Bean Pajak Di Bursa Efek Indonesia. Jurnal Lentera Akuntansi.

Hery. (2015). Analisis Kinerja Manajemen. Gramedia Widiasarana Indonesia.

Kemenkeu. (2020, September). Retrieved from https://www.kemenkeu.go.id/publikasi/berita/menkeupaparkan-realisasi-penerimaan-perpajakan-hingga-agustus-2020/

Kieso, D. E., Weygandt, J. J., \& Warfield, T. D. (2017). Akuntansi Keuangan Menengah Intermediate Accounting. Salemba Empat.

Mardiasmo. (2018). Perpajakan Edisi Terbaru 2018. Yogyakarta: ANDI.

Martani, D. (2012). Akuntansi Keuangan Menengah Berbasis PSAK. Raja Grafindo Persada.

Pasaribu, A. M. (2017). Pendapatan Usaha dan Beban Operasional Terhadap Laba Bersih Pada Perusahaan Makanan dan Minimum. Jurnal Wira Ekonomi Mikroskil.

Remofa, Y. (2019). Pengaruh Pendapatan Dan Biaya Operasional Terhadap Beban Pajak PT Belilas Permai Indragiri. Jurnal Manajemen dan Bisnis.

Suharli, M., \& Herfan, D. (2009). Pelaporan Keuangan Sesuai dengan Prinsip Akuntansi. Jakarta: Grasindo.

Sukmawati, E. (2020). Pengaruh Pendapatan dan Beban Perusahaan Terhadap Laba Pada PT Beta Mandiri Wiradana Prabumulih. Akuntanika.

Wagini., Andalas, D., \& Susena, K.C., (2019). Analisis Pengaruh Pendapatan Dan Beban Terhadap Pajak: Laba Sebelum Pajak Sebagai Variabel Intervening Pada PT Bank Bengkulu. Ekombis Review: Jurnal Ekonomi dan Bisnis.

Waluyo. (2017). Perpajakan Indonesia. Jakarta: Salemba Empat.

Zulkarnain, M. (2020). Pengaruh Total Aktiva dan Pendapatan Terhadap Laba Bersih (Studi Perusahaan Perbankan LQ45 BEI). Journal of Applied Administration. 